\title{
Kompetansebehov hos nytilsatt politi
}

\author{
AfKjersti Hove ${ }^{1}$
}

\begin{abstract}
This study considers the competencies that newly employed police recruits consider necessary for their work and compares them to the competencies actually acquired in the course of their formal education. The study is based on an electronic questionnaire which was sent to newly employed police officers two to four years after they had finished their studies. The aim of the study is to shed light on the Police's understanding of its own profession by examining new recruits' perceptions of their competencies and education. The study examines which types of competencies new recruits consider most important for their work and compares this to the competencies acquired in connection with their education (Bachelor's degree). Competencies examined in the study include knowledge, skills, abilities, properties, and other factors considered important for police work. The study also has a comparative element as its concerns are compared with corresponding issues in studies of teachers, nurses, and social workers."
\end{abstract}

\section{Bakgrunn}

Diskusjoner om hvilke type kompetanse som er viktigst for profesjoners yrkesutøvelse føres i alle profesjoner og profesjonsutdanninger (Molander og Terum, 2008). I Norge har debatten om profesjonsutdanningenes verdi vært sterkt debattert i kjølvann av NOKUTs gjennomgang av sykepleierutdanningene i 2004-2005 hvor konklusjonen var at fagområdet ennå ikke var etablert på tilstrekkelig akademisk nivå. Kompetansebehov og utdanning diskuteres også i politiet i alle de nordiske land og da kanskje spesielt forholdet mellom utdanningens relevans og tilpasning til det ordinære universitets- og høgskolesystemet (Sørensen, 2010, Danielsson, 2010). Mens vi ved Politihøgskolen i Norge arbeider for å opprettholde og utvikle vår akkrediterte bachelorutdanning har Per Sandberg i Fremskrittspartiet tatt til orde for at politiet i mindre grad trenger formell kompetanse enn det som er kravet i dag, at soldater med erfaring fra patruljering i Afghanistan kan utføre politiarbeidet vel så godt som politiutdannet personell:

* Title in English: Necessary Competence among New Police Recruits. 
»Flere års studier er unødvendig for å ta fingeravtrykk, for å etterforske og for å knipe råkjørere. Ett år holder i massevis. Du trenger ikke Politihogskolen for å patruljere i gatene « (NTB redaksjonen, 2010).

Utspillet til Sandberg ble fulgt opp i Magasinet Norsk Politi. Her ble polititjenestemenn og politihøgskolestudenter intervjuet om deres behov for kompetanse. I denne og andre diskusjoner om kompetansebehov og profesjonsutdanning settes gjerne teoretisk og praktisk kunnskap opp mot hverandre og det føres også en retorikk mellom utdanningens »akademiske« og »erfaringsbaserte« innholdselementer. En politioverbetjent fra Romerike politidistrikt setter diskusjonen på spissen med følgende uttalelse;

„Politiutdanningen i dag er altfor lite praktisk rettet. Vi må få tilbake fokuset på polititaktisk arbeid ... I dag vet politibetjentene alt om hva de ikke har lov til, men de vet ikke hva de faktisk skal gjøre for å fange en lovbryter. De er ikke sultne lenger, og da har vi tapt mye ... Dette er et stort fagfelt, men ønsker folk mer akademisk utdanning, kan de ta det andre steder enn på Politihogskolen« (Pedersen, 2010).

I dag pågår det flere nasjonale og internasjonale forskingsprosjekt som tar sikte på å studere profesjoners kompetanseutvikling. De siste årene har Senter for Profesjonsstudier (SPS) ved HiO løftet diskusjonen frem via flere studier om studenter og nyutdannedes syn på utdanning og yrkesutøvelse. I disse studiene står StudData santralt. ${ }^{2}$ Ved Politihøgskolen følges også utdanningsbehovet opp gjennom interne undersøkelser av politistudenters og nyutdannede sitt syn på kompetanse og utdanning. Mye tyder på at studenter og nytilsatte er fornøyd med utdanningen. I en kandidatundersøkelse fra 2006 finner Hansen at politihøgskolens grunnutdanning står $\mathrm{i}$ en særstilling som høgskole når det gjelder motivasjon (Hansen, 2006). I en avsluttende studentevaluering fra 2008 finner vi at avgangskullet er svært fornøyd med studiet (Hove, 2008). Også andre studier bekrefter at motivasjonen ved Politihøgskolen skiller seg ut i positiv retning (Fekjær, 2011).

Politihøgskolens kandidatundersøkelser rettes mot nyutdannede tjenestemenn og har til hensikt å undersøke hvordan nyutdannede selv oppfatter utdanningens verdi etter 2 til 4 års arbeid. I kandidatundersøkelsen som ble gjennomført våren 2010 ble generelle spørsmål om kompetanse fra StudData innlemmet. Grunnen til dette var ønsket om å fokusere på bredden i kompetansebehovet, uavhengig av de ulike fagelementene i utdanningen og for å se om polititjenestemennenes vurdering skiller seg fra øvrige profesjonsgrupper.

Spørsmål som stilles i denne studien er som følger: 
- Hvilken type kompetanse anser nyutdannet politi som viktig i sitt arbeid?

- Mener kandidatene at de har fått denne kompetansen gjennom utdanningen?

- Skiller vurdering av kompetansebehov og tilegnelse av kompetanse seg ut fra andre profesjonsgrupper?

I artikkelen gjør jeg først rede for de metodiske valg som er foretatt i studiet, respondentgruppen og studiets begrensninger. Deretter presenteres og drøftes funn fra analysen.

\section{Metodevalg og begrensninger}

Studien baserer seg på Politihøgskolens Kandidatundersøkelsen fra våren 2010, en undersøkelse som først ble gjennomført i 2006 (Hanssen 2006). Undersøkelsen ble utformet som en elektronisk spørreundersøkelse i Questback og distribuert til kandidater fra avgangsklassene i 2006 og 2008 (i alt 536) og deres ledere via Politiets datasystem (Bråten 2010). Datamateriellet er analysert i SPSS.

I undersøkelsen fra 2010 ble det lagt til spørsmål fra StudData som omhandler vurdering av tilegnelse av kompetanse gjennom politiutdanningen og behovet for kompetanse i arbeidssituasjonen. Det er disse spørsmålene som analyseres i denne studien. Det er i alt 18 kompetanseområder som det bes tas stilling til. ${ }^{3}$ Kandidatene blir bedt om å angi hvor viktig denne kompetansen er i sitt arbeid, på en skala fra 1-5 hvor 1 angir $i$ meget stor grad og 5 angir $i k k e ~ i$ det hele tatt. Kandidatene blir deretter bedt om å vurdere de samme kompetanseområdene sett i forhold til i hvilken grad de hadde tilegnet seg denne type kompetanse gjennom høgskoleutdanningen. I analysen er skalaen endret til en verdi fra 0-4 hvor 0 angir lav verdi mens 4 angir høy verdi. Dette er gjort av hensyn til muligheten for å kunne sammenlikne funne med andre undersøkelser hvor denne skalaen er benyttet.

Begrepet kompetanse handler om ens evne til å være kvalifisert for, eller kunne håndtere, en bestemt oppgave (Ellström, 1992). I flere studier som tar utgangspunkt i StudData skilles det mellom ulike former eller typer av kompetanse. De ulike kompetanseformene konstrueres via sammenslåing av ulike kompetanseområder fra spørreskjemaet i StudData gjennom faktoranalyser. I en studie av Heggen og Damsgaard (Heggen 2010), opereres det med tre kompetanseområder; teoretisk kompetanse (konstruert av kompetanseområdene Bred, generell kunnskap, Yrkesspesifikk kunnskap, Kunnskap om planlegging og organisering, Innsikt i regler og bestemmelser), praktisk kompetanse (konstruert av kompetanseområdene Praktiske ferdigheter, Evne til å arbeide under press, Evne til å jobbe selvstendig) og relasjonell kompetanse (konstruert av kompetanseområdene 
Muntlig kommunikasjonsevne, Toleranse, evne til å verdsette ulike synspunkter, Etisk vurderingsevne, Evne til innlevelse i andre menneskers situasjon).

Studien til Heggen og Damsgaard baserer seg på en undersøkelse som omfattet totalt 523 sosialarbeidere ( 217 sosionomer, 181 barnevernspedagoger, 125 vernepleiere), 549 lærere, 551 sykepleiere. Disse svarte på fase 3 av en StudDataundersøkelse tre år etter at de gikk i 6 . semester ved studiet. Ved å benytte de samme variabler og strukturer i min studie har det vært mulig å sammenlikne polititjenestemenns syn på kompetanse med disse profesjonsgruppene.

Politiutdanningen i Norge er i dag innlemmet i det ordinære høgskolesystemet og det anses derfor som spesielt viktig å innlemme et komparativt element i denne studien. Det er viktig å avdekke hvilken type kompetanse nyutdannet politi legitimerer og bygger sitt politiarbeid på og se om dette skiller seg ut fra andre profesjonsgrupper. I og med at Politihøgskolen er en ung høgskole (etablert i 1992 og med fullverdig akkreditering fra 2004) oppfatter mange at våre studenter orienterer seg på en annen måte i utdanningen enn studenter i andre profesjonsstudier. Politihøgskolestudenten oppfattes gjerne som mer praktisk enn teoretisk orienterte enn studenter fra de øvrige høgskoleutdanningene selv om det ikke er forskningsfunn som underbygger dette. Denne studien tar sikte på å gi oss noen holdepunkter i en slik komparativ analyse.

Heggen og Damsgaard baserer seg på et spørreskjema i papirform som ble sendt i posten til kandidatene etter at de hadde arbeidet i 3 år. Våre kandidater besvarte et spørreskjema i elektronisk form og hadde 2 eller 4 års erfaring fra politiarbeid. Analysene av politikandidatenes vurderings viser at det kun i begrenset grad fremkommer signifikante forskjeller i vurderingene mellom de to kullene og det antas derfor at erfaring fra 2 eller 4 års arbeid kan sammenliknes med Heggen og Damsgaards studie av kandidater som har 3 års yrkeserfaring. Det er uvisst om forskjellen i innsamling av data har betydning for de funn som er gjort.

Det eksisterer ulike betegnelser for den yrkesgruppen som er formelt utdannet til å arbeide som politi. I denne studien benytter jeg både den formelle betegnelsen polititjenestemann og de mer uformelle betegnelsene politi og tjenestemann om hverandre.

Bruk av sammenlikningsstandarder og kvantitative metoder har allmenne begrensinger; gjennom å stille spørsmål og svare på disse oppstår behovet for å stille flere. Kvalitative intervju vil kunne være en god metode for å fange opp de nyanser som analysene av datagrunnlaget ikke gir tilstrekkelige svar på. Dette har jeg ikke fått anledning til i denne omgang. En annen begrensing i studien er at jeg ikke har benyttet datagrunnlaget fra Heggen og Damsgaard i mine komparative 
analyser, men henviser kun til funn som fremkommer fra deres studier. Dette medfører at sammenlikningene ikke er testet ut med tanke på signifikans.

\section{Respondentgruppen}

298 av 536 kandidater responderte på undersøkelsen, dette utgjør $56 \% .36 \%$ av respondentene ferdigstilte studiet i 2006 mens $63 \%$ av kandidater ferdigstilte studiet i 2008. Respondentgruppen er representativ med tanke på kjønn og studiested. $25 \%$ av respondentene studerte i Bodø og $75 \%$ i Oslo. $35 \%$ kvinner responderte. $66 \%$ av respondentene er i alderen $26-30$ år mens $24 \%$ er i alderen 31 35 år.

$19 \%$ av respondentene oppgir at de ikke har høyere utdanning utover Politihøgskolen, $30 \%$ har gjennomført befalsskole mens $43 \%$ har, i tillegg til politiutdanningen, utdanning fra høyskole-/universitetsnivå uten fullført grad. $14 \%$ oppgir at har fullført annen høgskoleutdanning.

Nytilsatte i politiet har primært arbeidsoppgaver innen ordenstjeneste. Dette gjelder spesielt tilsatte på politistasjonene. Ved mindre lensmannskontorer vil arbeidsoppgavene også gjelde etterforskningsoppgaver og mer spesifikke, forebyggende tiltak. $26 \%$ av respondentene har hovedvekt av sin erfaring fra lensmannsetaten ( 76 personer), $64 \%$ har sin erfaring hovedsakelig fra en politistasjon, $7 \%$ har sin erfaring fra både lensmannsetaten og politistasjon mens kun $3 \%$ har oppgitt at de jobber i et særorgan.

\section{Hvilken type kompetanse anses som viktig?}

Analysene viser at de nyutdannede polititjenestemennene oppfatter alle de tre kompetanseformene som viktige i sin yrkesutøvelse. På en skal fra 0-4 hvor 0 angir lav verdi og 4 angir høy verdi, angir de behovet til å ligge mellom 2,69 og 2,93. De to avgangskullene (2006 og 2008) vurderer i all hovedsak kompetansebehovet som likt. Det er heller ikke funnet signifikante forskjeller i respondentenes vurdering ut i fra kjønn, alder, utdanningsbakgrunn eller tjenestested. 
Figur 1: Nyutdannede polititjenestemenns vurdering av kompetansebehov vs. tilegning av kompetanse gjennom sin grunnutdanning

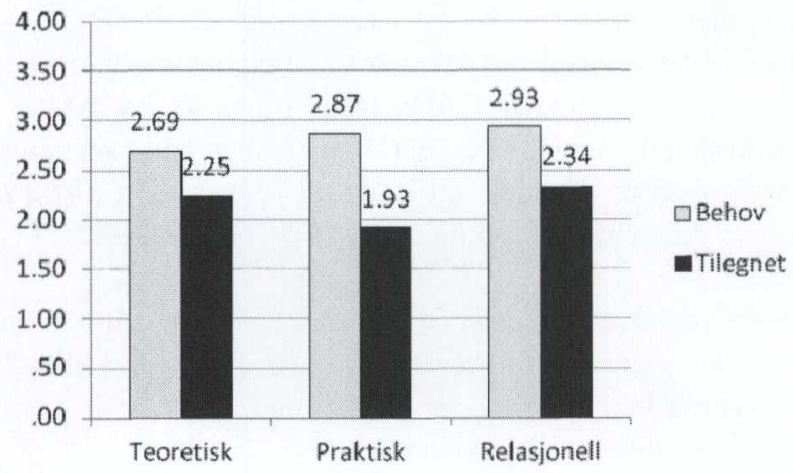

Teoretisk kompetanse (konstruert av kompetanseområdene Bred, generell kunnskap, Yrkesspesifikk kunnskap, Kunnskap om planlegging og organisering, Innsikt $i$ regler og bestemmelser), praktisk kompetanse (konstruert av kompetanseområdene Praktiske ferdigheter, Evne til å arbeide under press, Evne til å jobbe selvstendig) og relasjonell kompetanse (konstruert av Muntlig kommunikasjonsevne, Toleranse, evne til å verdsette ulike synspunkter, Etisk vurderingsevne, Evne til innlevelse $i$ andre menneskers situasjon). Bruk av skala fra $0-4$ hvor 0 angir lav verdi og 4 angir hoy verdi. $\mathrm{N}=298$. Funnene er signifikanstestet (sig nivå 0,05 ) ved å sammenlikne konfidensintervall.

Kandidatene oppgir i snitt størst behov for relasjonell kompetanse (2,93). Standardavviket er her 1,14, noe som indikerer at det er stor spredning i vurderingene. Hele $25 \%$ av kandidatene angir behovet til verdien 4 mens $12 \%$ av kandidatene vurderer denne kompetansen til 1 eller lavere. Av de kompetanseområdene som inngår i relasjonell kompetanse, oppgir kandidatene størst behov for muntlig kommunikasjonsevne $(3,15)$, jmf figur 2 . Behovet for relasjonell kompetanse angis som signifikant høyere enn teoretisk kompetanse. Det er ikke signifikante forskjeller mellom behovet for praktisk- og relasjonell kompetanse.

Behovet for praktisk kompetanse vurderes til et gjennomsnitt på 2,87. Også her er det stor spredning i vurderingen, standardavviket er 1,22. Vi finner en gruppe kandidater som vurderer kompetansebehovet som lavt; $18 \%$ legger seg på verdien 1 eller lavere. Av de kompetanseområdene som inngår i Praktisk kompetanse, oppgir kandidatene størst behov for Praktiske ferdigheter $(2,91)$.

Selv om Teoretisk kompetanse vurderes som mindre viktig enn de øvrige, tolkes funnene likevel slik at kandidatene anser behovet for teoretisk kompetanse som viktig i sitt arbeid. På en skala fra $0-4$, hvor 0 vurderes som høyt og 4 som 
lavt, legger kandidatene seg på et gjennomsnitt på 2,7. Kandidatene er noe mer samstemte i denne vurderingen, standardavviket er 0,97. En liten gruppe kandidater, $12 \%$, vurderer behovet for denne kompetansen som 1 eller lavere. Av de kompetanseområder som inngår i teoretisk kompetanse, vurderes behovet for Innsikt i regler og bestemmelser som høyest $(2,70)$.

Figur 2: Nyutdannede polititjenestemenns vurdering av kompetansebehov versus tilegning av kompetanse gjennom utdanning, besvart gjennom 18 kompetanseområder

\section{8 kompetanseomräder; behov versus tilegning}

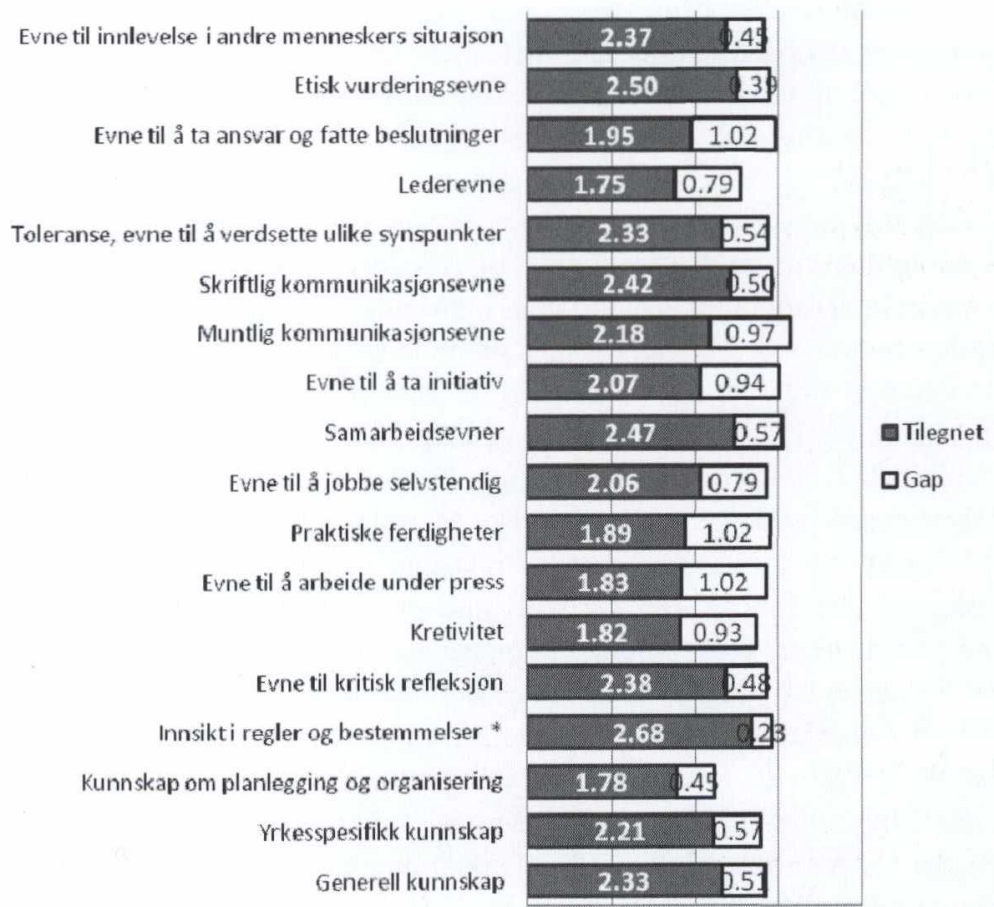

Hele søylen viser behovet for kompetanseområdet i yrket. Den venstre delen av søylen viser i hvor stor grad en har tilegnet seg denne kompetansen i utdanningen. Høyre del av søylen viser gapet mellom behov og tilegning. Bruk av skala fra 0-4 hvor 0 angir lav verdi og 4 angir høy verdi. $\mathrm{N}=298$. Forskjellen mellom vurdering av kompetansebehov og tilegnet kompetanse er signifikant for alle kompetanseområder ( 0,05 nivå) sett bort fra kompetanseområdet Innsikt $i$ regler og bestemmelser. Signifikansnivå er analysert ved å sammenlikne konfidesintervall. 


\section{Har de tilegnet seg den kompetansen som de oppfatter at de har behov for?}

Figur 1 viser et gap mellom de nytilsattes behov for kompetanse og deres vurdering av tilegnelsen av denne kompetansen gjennom utdanningen. De vurderer sitt behov for teoretisk, praktisk og relasjonell kompetanse som signifikant større enn tilegnet kompetanse gjennom sin utdanning. Et hovedfunn $i$ analysen er at kandidatene oppgir at de i snitt har tilegnet seg minst praktisk kompetanse. Sett i lys av funn fra tidligere studentundersøkelser er det ikke overraskende at læringsutbyttet vurderes som minst innen praktisk kompetanse. Studentene ved Politihøgskolen har i flere år oppgitt at behovet for praktisk kompetanse er sterkt, de foretrekker praktisk rettede emner og de lærer best gjennom praksis og praktiske øvelser enn gjennom auditorieundervisninger og litteraturstudier (Hove, 2010). Erfaringsbasert kunnskap står også sentralt i politiet. Dette kommer også klart til uttrykk i intervjuer i Politidirektoratets tidsskrift Magasinet Norsk Politi (2010:1). Det er kanskje mer overraskende at kandidatene oppgir størst læringsutbytte innen relasjonell kompetanse. Analysen viser at det er signifikant forskjell mellom studentenes tilegning av praktisk og relasjonell kompetanse. Vi finner ikke signifikant forskjell mellom tilegning av teoretisk- og relasjonell kompetanse. Det at studentene mener at utdanningen har gitt dem nødvendig relasjonskompetanse, bekreftes også gjennom andre studier av kandidatundersøkelsen (Bråten, 2010).

Kandidatenes vurdering av tilegnet relasjonskompetanse legger seg på et gjennomsnitt på 2,34. Studentene er rimelig samstemte i denne vurderingen, standardavviket er 0,78. Det kompetanseelementet som kandidatene oppfatter som mest vesentlig for sin yrkesutøvelse, Muntlig kommunikasjonsevne, vurderes imidlertid som minst tilegnet av de relasjonelle kompetanseområdene med et snitt på 2,18. Her finner vi det største kompetansegapet i de atten kompetanseområdene. Årsakene til dette tydelige kompetansegapet kan forstås ut i fra et stort behov for denne type kompetanse (Lagestad, 2010) og en for lite vektlegging av dette i det formelle studiet. Dette innholdselementet er styrket i utdanningen fra studieåret 2009/2010. Det elementet innen relasjonskompetanse som vurderes som mest tilegnet er Etisk vurderingsevne med et snitt på 2,50. Dette kompetanseområdet ble først formelt innlemmet i politiutdanningen i den treårige høgskoleutdanningen i 1992. Siden da er kompetanseområdet blitt styrket i tverrfaglige temaperioder fra studieåret 2003/2004 og inngår i dag som eget, tverrfaglig emne. Det er vel likevel grunn til å tro at dette kompetanseområdet oppfattes som mer »håndfast « å vurdere enn de øvrige kompetanseområdene innen relasjonskompetanse og at dette kan være noe av årsaken til denne vurderingen. 
Sett ut i fra utdanningens studieplaner, er teoretisk kompetanse utdanningens bærende element. Studentevalueringer viser at studentene oppfatter at dette er den kompetanse som først og fremst tilegnes i utdanningen (Hove, 2008). De nyutdannede vurderer derimot sin tilegnelse av teoretisk kompetanse til et gjennomsnitt på 2,25. Selv om de fleste av de utvalgte kompetanseområdene står sentralt i utdanningens studieplaner, i undervisning og ved eksamen, oppgir kandidatene at de har tilegnet seg denne form for kompetanse i moderat grad. Kandidatene er relativt samstemte i denne vurderingen, standardavviket ligger på 0,58 . Funnet viser at studenter og nyutdannede har ulik vurdering av sin tilegning av teoretisk kompetanse gjennom utdanningen. Det kompetanseområdet som de nytilsatte vurderer som best tilegnet er Innsikt i regler og bestemmelser med et snitt på 2,68. Til forskjell fra de 17 andre kompetanseområdene, finner vi ikke signifikante forskjeller mellom kandidatenes vurdering av behov og tilegnet kompetanse når det gjelder dette kompetanseområdet. Innsikt i regler og bestemmelser er et sentralt innholdselement $\mathrm{i}$ utdanningen som studenter i utdanningen også mener de făr godt utbytte av gjennom utdanningen (Hove 2008, Hansen 2006, NOU 1979). Dette kan forklares ved at juridisk kompetanse har vært det bærende kompetanseområdet i politiutdanningen siden opprettelsen av den statlige politiutdanningen i 1919 (Leonardsen, 1972).

Studentene har i flere år hevdet at praktisk kompetanse får for liten plass i utdanningen. Kandidatenes vurdering av denne kompetansetilegningen er i gjennomsnitt 1,93 og samsvarer på mange måter med studentenes vurdering. Det er relativt lite sprik i gruppens vurdering her, standardavviket er 0,73 . Selv om studentene oppfatter det slik at praksis får for liten plass i studiet, viser studieplanene at hele $1 / 3$ av studiet er veiledet praksis ved en politistasjon eller et lensmannskontor. De to øvrige studieårene er også preget av praktiske øvelser integrert i teoriundervisning og en egen operativ periode $\mathrm{i} » l$ leir«. Oppfatningen tolkes som et uttrykk for hvor stor verdi den praktiske kompetansen har hos de nyutdannede og i politiet generelt.

Analysene viser at det ikke er store forskjeller i vurderingene mellom kullene, kjønn, alder, tjenestested eller studiested. 2008-kullet oppgir at de har tilegnet seg noe høyre teoretisk kompetanse enn 2006-kullet (sig 0,026). Det ble ikke gjennomført store endringer i studieplaner eller undervisning for dette kullet, så den ulike vurderingen kan neppe skyldes endret innhold. I studier av andre profesjonsutdanninger finner man en klar sammenheng mellom en synkende verdisetting av kompetansetilegning og antall år i praksis. Det kan være den samme tendensen som slår inn hos våre kandidater også. Sammenlikningen av funn fra avsluttende evaluering for kullet som gikk ut i 2008 bekrefter også denne trenden. 
Analysene viser at kvinnene angir en hoyere tilegning av praktisk kompetanse enn menn, uavhengig av kulltilhørighet (sig nivå 0,001). Årsaken til dette tydelige funnet er uklart. Til tross for at det er en økende andel kvinner som arbeider i politiet, regnes politiyrket for å være mannsdominert. En forklaring på dette funnet kan være at kvinnelige studenter erfarer den praktiske kompetansen som betydelig annerledes enn den kompetanse de har ervervet tidligere og derfor opplever en brattere læringskurve innen disse kompetanseområdene enn sine mannlige kolleger. Dette gjelder kanskje i størst grad den praktiske kompetansen som tilegnes i studentenes praksisår.

\section{Sammenlikning med andre profesjonsgrupper}

Sett i forhold til de øvrige profesjonsgruppene er det to interessante forhold som tydeliggjøres i datamaterialet; nytilsatte politifolk viser mindre behov for kompetanse enn de øvrige profesjonsgruppene innen alle tre angitte kompetanseformer. Videre er kompetansegapet mellom oppfattet behov og tilegnet kompetanse generelt sett lavere hos politikandidatene enn hos de øvrige profesjonsgruppene.

\section{Teoretisk kompetanse}

Sett i forhold til utvalget i Heggen og Damsgaard (figur 3), vurderer polititjenestemennene det teoretiske kompetansebehovet som klart lavest av profesjonsgruppene. Dette tolkes som om at de opplever at arbeidet i mindre grad krever teoretisk kompetanse enn det de øvrige profesjonsgrupper opplever, eventuelt at det oppfattes slik. Dette kan skyldes at politiarbeidet hos nyutdannede generelt preges mindre av kunnskapsbasert arbeid enn arbeidet hos de øvrige profesjonsgruppene og at det, objektivt sett, ikke krever større teoretisk kompetanse for å utføre dette. Som vist tidligere, arbeider nyutdannet politi i første rekke innen operativt politiarbeid/ordenstjeneste. Fagplanene i bachelorutdanningen legger stort fokus på forberedelser til politiets ordensoppgaver og viser at ordensarbeid, formelt sett, bør bedrives ut i fra et bredt kunnskapsgrunnlag. Historisk sett har politiet selv oppfattet arbeid i ordenstjenesten som mindre teoretisk krevende enn politiarbeid innen etterforsking (Leonardsen, 1972). Stadige innlegg i Politets Fellesforbunds medlemsblad, Politiforum, viser at flere tjenestemenn har den samme oppfattning i dag.

Funnet kan også forklares ut $\mathrm{i}$ fra at polititjenestemennene i mindre grad klarer å se den praktiske betydningen av den teori de har tilegnet seg i utdanningen enn de øvrige profesjonsgrupper. En hypotese kan også være at teoretisk kunnskap generelt har mindre verdi i politiets organisasjonskultur enn hos de øvrige profesjonsgrupper og at de nyutdannede kandidatene påvirkes av denne kulturen. 
Figur 3: Kompetansebehov i yrket på området teoretisk kompetanse

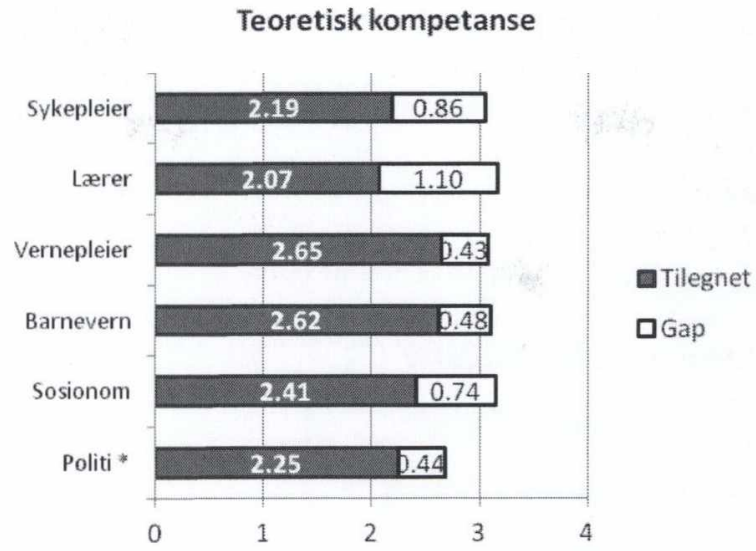

I teoretisk kompetanse inngår kompetanseområdene Bred, generell kunnskap, Yrkesspesifikk kunnskap, Kunnskap om planlegging og organisering, Innsikt i regler og bestemmelser. Hele søylen viser behovet for teoretisk kompetanse i yrket. Den nederste delen av søylen viser i hvor stor grad en har tilegnet seg denne kompetansen $\mathrm{i}$ utdanningen. Overste del av søylen viser gapet mellom behov og tilegning. Bruk av skala fra $0-4$ hvor 0 angir lav verdi og 4 høy verdi. Figuren er bearbeidet etter figur 6.2 i Heggen og Damsgaard, 2010. Data fra kandidatundersøkelsen er lagt til den opprinnelige figur.

I alle profesjonsgrupper ser vi en tydelig avstand mellom behovet for kompetanse og tilegnet kompetanse. Ifølge Heggen og Damsgaard uttrykker et lavt kompetansegap innen teoretisk kompetanse at utdanningens innhold samsvarer med behovet i praksis. For politiutdanningens del er dette en tolkning som både kan oppfattes som positivt. Det lave kompetansegapet kan for eksempel bero på at det teoretiske innholdet samsvarer med forventningen om yrkets arbeidsoppgaver og en positiv vurdering av kvaliteten på det innholdet som blir gitt (undervisningen og pensumlitteraturen). Heggen og Damsgaard viser også en annen måte å forstå et stort kompetansegap som det at det innen enkelte utdanninger er mer komplisert å utvikle teoretisk kompetanse. Det er spesielt lærerne som her trekkes frem. Denne tolkingen kan støtte hypotesen om at politiarbeidet oppleves som mindre teoretisk krevende hos de nytilsatte polititjenestemennene enn hos flere av de andre profesjonsgruppene. 


\section{Praktisk kompetanse}

I følge Heggen og Damsgaard vurderer alle nyutdannede i de fem profesjonene et høyt behov for praktisk kompetanse. Polititjenestemennene vurderer behovet for praktisk kompetanse som lavere enn de øvrige profesjonsgruppene, men de mener at de, i større grad enn andre, har fătt denne kompetansen gjennom utdanningen.

Figur 4; Kompetansebehov i yrket på området praktisk kompetanse.

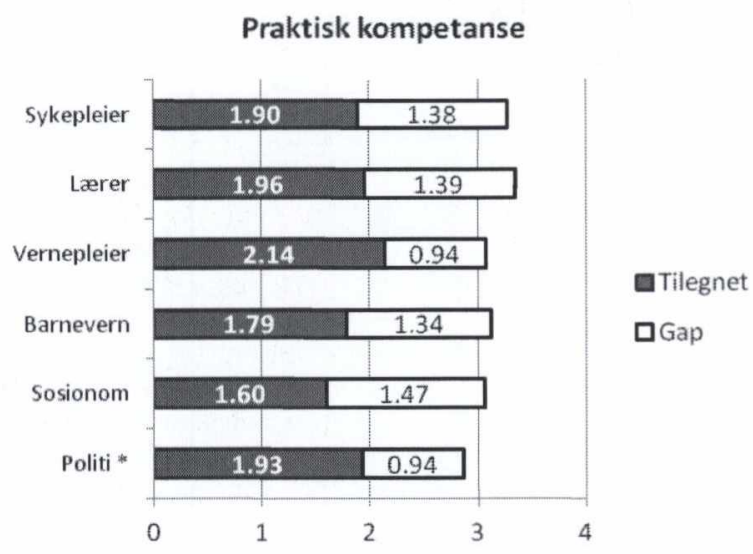

I praktisk kompetanse inngår kompetanseområdene Praktiske ferdigheter, Evne til å arbeide under press samt Evne til å jobbe selvstendig. Hele søylen viser behovet for praktisk kompetanse i yrket. Den nederste delen av søylen viser i hvor stor grad en har tilegnet seg denne kompetansen $\mathrm{i}$ utdanningen. Overste del av søylen viser gapet mellom behov og tilegning. Bruk av skala fra 04 hvor 0 angir lav verdi og 4 høy verdi. Figuren er bearbeidet etter figur 6.2 i Heggen og Damsgaard, 2010. Data fra kandidatundersøkelsen er lagt til den opprinnelige figur.

Det generelt lave kompetansebehovet hos de nytilsatte tjenestemennene tolkes som en hovedårsak til den lave vurderingen av også praktisk kompetanse. Det er uansett interessant at de øvrige profesjonsgruppene oppfatter behovet for praktisk kompetanse som større enn polititjenestemennene. Det kan derfor være grunnlag for å studere nærmere om det er de mer spesifikke kompetanseområdene innen praktisk kompetanse som gir dette utslaget i forhold til andre profesjonsgruppene. Det kan f. eks være interessant å studere nærmere om de andre profesjonsgruppene mener at de opplever større grad av selvstendighet og mer press i sitt arbeid enn det polititjenestemennene oppgir.

I diskusjoner om høyere utdanning i Norge har flere stilt spørsmål ved om utdanningene har blitt for teoretisk og akademiske sett i forhold til de oppgaver 
som skal utføres (Heggen, 2010). Det er derfor interessant å merke seg at alle profesjonsgruppene vurderer kompetansegapet som størst innen praktisk kompetanse. Kompetansegapet er imidlertid minst hos polititjenestemennene. Heggen og Damsgaard tolker kompetansegapet innen praktisk kompetanse som et uttrykk for at praksis ikke tilegnes i formell utdanning, men i yrkessammenheng. I lys av denne tolkingen kan et mindre opplevd kompetansegap hos polititjenestemennene forstås som at Politihøgskoleutdanningen skiller seg ut fra de øvrige i det å bedre ivareta praktisk kompetansetilegning i utdanningen.

\section{Relasjonell kompetanse}

Relasjonell kompetanse er ofte omtalt i utdanningers overordnede målsettinger, men er ofte vanskelig å målfeste $\mathrm{i}$ konkrete undervisningsmål og i eksaminering. Grunnen til dette er at dette kompetanseområdet i stor grad innebærer personlig egnethet og holdningselementer eller det Ellstrôm beskriver som »ideologisk/normativ« kompetanse (Lindholm, 2006).

Det er interessant å merke seg at alle profesjonsgruppene i Heggen og Damsgaards studie vurderer relasjonell kompetanse som mest vesentlig av de tre kompetansegruppene. Kompetansegapet angis som lavest hos polititjenestemennene.

Figur 5: Kompetansebehov i yrket på området relasjonellkompetanse

\section{Relasjonell kompetanse}

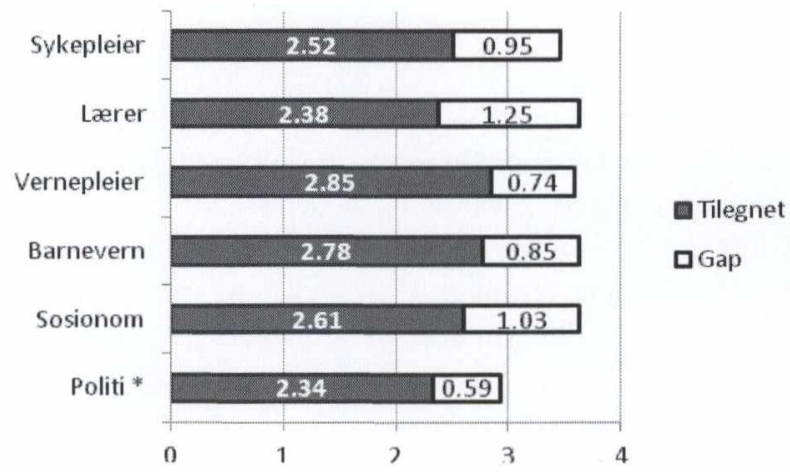

I relasjonell kompetanse inngår kompetanseområdene Muntlig kommunikasjonsevne, Toleranse, Evne til å verdsette ulike synspunkter, Etisk vurderingsevne og Evne til innlevelse i andre menneskers situasjon. Hele søylen viser behovet for relasjonell kompetanse i yrket. Den nederste delen av søylen viser i hvor stor grad en har tilegnet seg denne kompetansen i utdanningen. Øverste del av søylen viser gapet mellom behov og tilegning. Bruk av skala fra 0-4 hvor 0 angir 
lav verdi og 4 høy verdi. Figuren er bearbeidet etter figur 6.2 i Heggen og Damsgaard, 2010. Data fra kandidatundersøkelsen er lagt til den opprinnelige figur.

Politikandidatene vurderer også behovet for relasjonell kompetanse som størst av de tre kompetanseformene. Dette funnet samsvarer med andre deler av Kandidatundersøkelsen (Bråten, 2010). Dette overrasker kanskje noe i og med at retorikken i diskusjoner om utdanningens verdi som oftest knyttes til praktisk versus teoretisk kompetanse. I diskusjoner om politiutdanningen omtales ofte behovet for evne til muntlig kommunikasjon, men ikke relasjonskompetanse generelt.

De variabler som her utgjør relasjonskompetanse oppfattes tradisjonelt som mer forenlige med de tradisjonelle, kvinnedominerte omsorgsyrker. I datamaterialet finner vi likevel ikke signifikante forskjeller mellom menn og kvinners vurdering av behovet for relasjonskompetanse. Funnet samsvarer med Rønnebergs studie av samtalene mellom »politivakta« og publikum (Rønneberg, 2009). Hun finner, til forskjell fra Lagestad (Lagestad, 2010), at kjønn ikke har betydning for hvordan polititjenestemenn- og kvinner kommuniserer med publikum. Rønnebergs funn kan tolkes som at kvinnene i politiet assimileres inn i mannskulturen i politiet. Det at polititjenestemenn oppfatter relasjonskompetanse som viktigst i sitt arbeid kan på den andre side også tolkes som at politikulturen har endret seg mot mer kvinnelige verdier i takt med kvinnenes inntog i yrket. Andre årsaker til økt vektlegging av relasjonskompetanse kan være utviklingen i samfunnet generelt og utviklingen $\mathrm{i}$ utdanningen spesielt. Rekrutteringsgrunnlaget til yrket (Larsson, 2010) kan også årsaksforklare denne utviklingen.

\section{Kompetansebehovet}

Et interessant hovedfunn i studien er at polititjenestemennene angir et gjennomgående, lavere behov for kompetanse innen alle kompetanseområder enn de øvrige profesjonsgruppene. Hvordan kan vi forstå dette?

Forkjeller mellom utdanninger kan analyseres og forklares både ut $\mathrm{i}$ fra egenskaper hos studentene som rekrutteres til studiet og gjennom egenskaper ved selve studiet. (Mastekaasa, 2003) peker på at sosialisering inn i en bestemt studiekultur vil forme studentenes forventninger til utdanningens innhold og form. På tilsvarende vis kan vi anta at organisasjonskulturens oppfatning av kompetanse og kompetansebehov vil prege de nytilsattes oppfatninger av kompetansebehov. Den enkelte kandidats vurdering i denne studien vil altså være preget av sosialisering i profesjonsutdanningen og i den profesjonskulturen der arbeidet foregår. Til tross for at egenskaper hos kandidatene uten tvil preger profesjonsgruppens vurdering av utdanningen, oppfattes egenskaper ved utdanningene likevel 
som hovedårsaken til at studenter vurderer utdanningene som forskjellige. På tilsvarende vis må vi kunne anta at kandidatenes vurdering er uttrykk for den organisasjonskultur de arbeider $\mathrm{i}$ og at deres vurderinger gir et bilde på organisasjonens syn på kompetanse.

På mange måter avdekker analysene en organisasjonskultur som er mer positiv til kompetanse som tilegnes i praksisfellesskapet og som er mer knyttet til personlig egnethet enn den som tilegnes gjennom litteraturstudier i en tradisjonell høgskoleutdanning. Ved å uttrykke et relativt lavt behov for teoretisk kompetanse og fremheve relasjonell kompetanse, viser kandidatene på mange måter at de mener at yrkesutøvelsen avhenger mer av personlig egnethet eller det som Ellstrôm betegner som ideologisk/normativ kompetanse (Lindholm, 2006) enn oppgaveorientert kompetanse som tilegnes gjennom utdanning og uttrykkes gjennom vitnemål. Graner avdekker tilsvarende funn hos »ordenspolitiet« i Sverige (Granér, 2004). Han hevder at denne del av politiet preges av et kunnskapssyn som er handlingsorientert, utgått fra konkrete og selvopplevde hendelser. Dette er kunnskap som man på mange måter kan beskrive som uartikulert og taus (Schön, 1991). Denne kunnskapskulturen assosieres gjerne til håndverksyrker hvor »svennen« tilegner seg yrket gjennom råd og oppfølging av en »mester« (Handal og Lauvås, 1983). Gundhus beskriver delvis den samme kunnskapskulturen ved Ordensavsnittet ved Oslo politistasjon (Gundhus, 2009). Her finner hun at tjenestemennene er mer opptatt av opplevelse enn analytisk kunnskap. Et hovedfunn hos henne er at politiets yrkeskultur har liten tradisjon for kunnskapsarbeid forstått som det å ta beslutninger og praktisere politiarbeidet ut i fra bredt funderte kunnskapstilfang og innsikter. Graner stiller spørsmål om kunnskapskulturen i »ordenspolitiet« kan beskrives som antiintellektuell. Ut i fra våre analyser må det samme spørsmålet kunne stilles til organisasjonskulturen som våre kandidater arbeider i og kanskje aller helst til den gruppen kandidater som analysene viser angir verdien på kompetansebehovet til være lik 1 eller mindre.

Det er interessant å merke seg at det i flere politidistrikt inntil nylig var vanlig å fokusere mer på »egnethet« ved tilsettinger enn at kandidatene hadde bestått alle fag i utdanningen og kunne vise til vitemål første arbeidsdag. Det at politikulturen i så sterk grad vektlegger handlingsorientert og personorientert kompetanse kan forstås i lys av det etablerte opptakssystemet ved Politihøgskolen, en tradisjon som vi ikke finner i de øvrige profesjonsutdanningene. I tillegg til studiekompetanse vektlegges en fysisk opptaksprøve og vurdering av personlig egnethet gjennom intervju. En revisjon av høgskolens fysiske opptaksprøver skapte dette studieåret stort engasjement langt ut over høgskolens grenser og viste hvilket sterkt symbol fysiske ferdigheter har i politiet. Opptakssystemet kan slik sett fungere som en 
utilsiktet, skjult læreplan for både studenter og tilsatte i politiet og bidra til å opprettholde en kompetansekultur som Graner karakteriserer som »antiintellektuell«.

\section{Kompetansegapet}

Et annet hovedfunn i studiet er, sammenliknet med de øvrige profesjonsgruppene, det lave kompetansegapet hos politikandidatene. Dette kan oppfattes på flere måter. Først og fremst må funnet oppfattes som positivt for Politihøgskolen. (Heggen og Damsgaard, 2010) tolker lavt kompetansegap med at avstanden mellom utdanningens innhold og praksisfeltet er lite. For Politihøgskolens del er dette, organisatorisk sett, tilfelle. Politihøgskolen styres av to departement, både Justis- og politidepartementet og Utdanningsdepartementet. Politihøgskolens øverste leder er både rektor og politimester. Politihøgskolen er delvis lagt inn under Universitets- og høgskoleloven og styres etter de samme retningslinjer som andre akkrediterte høgskoler for øvrig. Grunnutdanningen fører til en akkreditert bachelorgrad. Som politimester deltar rektor i politimesterkollegiet og i styringsdialoger med Politidirektøren. Høgskolen får sin finansiering med eget kapittel over statsbudsjettet. Lærergruppen består i stor grad av erfarne tjenestemenn og kvinner med bred kompetanse fra praksisfeltet. Disse bringer dagsaktuelle emner og diskusjoner inn i klasserommet. I tredje studieår vektlegges erfaringer fra praksis og det legges vekt på å diskutere studentenes erfaringer fra praksisåret. Det andre studieåret foregår i praksis under veiledning av en erfaren tjenestemann.

Den tette koblingen med etaten medfører at det formelt og uformelt fanges opp signaler om behov for substansielle endringer i utdanningen. Fokus på såkalte »meningsfylte sammenhenger " (Grimen, 2008) identifiseres og legges som utgangspunkt for tverrfaglige undervisningsopplegg og undervisning $\mathrm{i}$ det enkelte emne. I ny rammeplan er slike meningsfylte sammenhenger tydeliggjort (Politihøgskolen, 2006). Utdanningens innhold er her organisert ut i fra politiets arbeidsfelt og ikke ut i fra vitenskapelige disipliner. Intensjonen er at man i enda større grad kan få til gode koblinger mellom et teorietisk, forskningsbasert innhold og praktiske innholdselementer slik innholdet i studieplanene samsvarer med kompetansebehovet i praksis og at kandidatene lettere ser overføring mellom den kompetanse som tilegnes i utdanningen og den kompetanse som oppgaven krever.

Den formelle vitenskapeliggiøringen av kunnskapsgrunnlaget til de øvrige profesjonsgrupper i denne studien startet lenge før tilfellet var for politiet (Slagstad, 2008). Deres formelle utdanningstilbud har i lengre tid vært del av det ordinære høgskolesystemet (Heggen, 2010). Politiet fikk sin treårige høgskoleutdanning først i 1992 og status som akkreditert bachelor i 2005. Det samme året ble masterstudiet opprettet. Politivitenskap er et ungt forskingsfelt ved Politihøgsko- 
len (Gundhus m. flere, 2010). Også på dette feltet er Politiet og Politihøgskolen kommet kort sett $\mathrm{i}$ forhold til andre profesjonsgrupper. Det er derfor grunn til å hevde at den tette koblingen til etaten og lav fartstid i Universitets og høgskolesektoren kan være en årsak til at kandidatene viser mindre behov for formell kompetanse enn de andre profesjonsgrupper. Et retorisk spørsmål vil derfor være om kompetansegapet vil holde seg like lavt hvis kompetansebehovet øker i takt med vitenskapeliggjøringen av politiarbeidet og politifolks fortrolighet med teoretisk kompetanse eller om gapet mellom kompetansebehov og tilegnet kompetanse vil øke tilsvarende som i de øvrige profesjonsutdanningene.

\section{Oppsummerende diskusjon}

I denne studien har jeg satt søkelys på hva som kjennetegner nyutdannede polititjenestemenns vurdering av kompetanse. Spørsmål som ble stilt var som følger:

- Hvilken type kompetanse anser nyutdannet politi som viktig i sitt arbeid?

- Mener kandidatene at de har fătt denne kompetansen gjennom utdanningen?

- Skiller vurdering av kompetansebehov og tilegnelse av kompetanse seg ut fra andre profesjonsgrupper?

Studien viser at nyutdannede polititjenestemenn viser tydelig behov for teoretisk, praktisk og relasjonell kompetanse i sitt politiarbeid. Dette er kompetanse som tilegnes gjennom den treårige bachelorutdanningen. Kandidatene viser mest behov for relasjonell kompetanse og minst behov for teoretisk kompetanse. Praktisk kompetanse angis å være minst tilegnet gjennom utdanningen. Evne til muntlig kommunikasjon oppfattes som det viktigste »våpenet « i politiarbeidet mens Innsikt i regler og bestemmelser angis som det enkeltstående kompetanseområdet som er best tilegnet mest gjennom studiet.

Studien viser, grovt sett, at nyutdannede polititjenestemenn angir et mindre behov for oppgaveorientert kompetanse enn sammenliknbare profesjonsgrupper. Dette funnet kan tolkes som at nyutdannet politi i mindre grad enn andre profesjonsgrupper baserer sin yrkesutøvelse på oppgaveorientert kompetanse og i større grad på ideologisk/normativ kompetanse som er mer preget av personlige egenskaper. Årsaken til dette kan være flere, for eksempel at politiarbeidet oppfattes som mindre komplekst og krever mindre teoretisk kompetanse hos nytilsatte enn hos de øvrige profesjonsgruppene, at nyutdannet politi ikke evner å dra nytte av sin tilegnede kompetanse i praktisk politiarbeid. En annen tolking kan være at de nyutdannede blir påvirket av en kompetansekultur som er lite kunnskapsbasert.

Det mye omtalte »praksissjokket« finner vi ikke i like stor grad i politiet som i de øvrige profesjonsgruppene. Dette funnet tolkes som at politiutdanningen »tref- 
fer« utdanningsbehovet bedre enn hos de øvrige profesjonsgruppene, at utdanningens innhold og form i stor grad samsvarer med de nytilsattes behov for kompetanse og den kompetansekultur som eksisterer i politiet. Dette må kunne tolkes som positivt for Politihøgskolen.

I ulike profesjonsstudier hevdes det at arbeidsoppgaver endres raskere enn tidligere og det pekes på en kunnskapseksplosjon som innebærer store konsekvenser for profesjonsutdanningene (Lahn og Jensen, 2008). Det må være grunn til å tro at utviklingen av kunnskapsbasert politiarbeid vil måtte utvikles på lik linje med de øvrige profesjonsgrupper etter hvert som kompleksiteten i politiarbeidet endres i takt med samfunnsutviklingen for øvrig. Politidirektoratet gir tydelige forventninger om kunnskapsbasert politiarbeid (Politidirektoratet, 2008). På bakgrunn av funn fra denne studien kan man likevel ha grunn til å anta at kunnskapsbasert arbeid i dag har mindre forutsetninger for å oppfylles i politiet (og da i særlig grad i operativt politiarbeid) enn hos de øvrige profesjonsgrupper hvor behovet for teoretisk kompetanse uttrykkes tydeligere enn hos våre kandidater. Dette er en utvikling som blir viktig å følge opp i tiden fremover.

Det må påpekes at det som kan være Politiutdanningens styrke også kan vise seg å være etatens akilleshæl. Etatstilknytning og fokus på praktisk nytteverdi av utdanningen kan samtidig være medvirkende til en konserverende kompetansekultur i politiet. For å kunne realisere kunnskapsbasert politiarbeid på alle nivå må polititjenestemennene selv oppdage at teoretisk kompetanse kan være relevant i det daglige arbeid. I så måte må det både gjennom utdanningen ved Politihøgskolen, fra ledere på alle nivå og gjennom fagforeningsarbeid synliggjøres hvilken det vil være å ta i bruk alle former for oppgaveorientert kompetanse i ordinært politiarbeid, også teoretisk kompetanse. For utdanningens del kan man på mange måter si at det er de samme utfordringer som vi i 2011 står overfor som Politiutdanningsutvalget av 1971 erfarte;

"Utvalget går uten videre ut fra at det er alminnelig enighet om at grunnutdanningen må være av både teoretisk og praktisk karakter. Det spørsmål som fortjener drøftelse, er hvorledes teori og praksis $i$ det som egentlig er en enhetlig utdanning, skal forenes og forholde seg til hverandre slik at de utfyller og beriker hverandre (NOU, 1979:11, s 35, min uthevelse).

I 2011 kan vi presisere utfordringen til å gjelde forholdet mellom erfaringsbasert kompetanse og forskningsbasert kompetanse. Begge må forholde seg til hverandre, utfylle og berike hverandre.

Profesjonsutdanninger kan ha ulike funksjoner. De skal først og fremst ha en kvalifiserende rolle. Utdanninger kan også oppstå som et resultat av yrkesgruppers strategier for å monopolisere adgangen til yrker og drive strategisk profe- 
sjonskamp (Smeby, 2009). Ambisjonen for oss som bedriver politiutdanning må være at den har en langt større verdi enn å fungere som »inngangsbillett« til et spennende yrke. Ambisjonen må være at kandidatene som uteksamineres er kompetente til å utføre politiarbeid av høy kvalitet, kan videreutvikle sin kompetanse i praksisfeltet og bidra til utvikling av politiet.

I Politihøgskolens forskningsprosjekt Rekruttering, utdanning og karriere $i$ politiet: en europeisk komparativ og longitudinell studie, tas det sikte på å følge politihøgskolestudenter gjennom hele studiet og seks år ut i arbeidslivet. Forskningsprosjektet innlemmer alle de skandinaviske politiutdanningene. Dette studiet vil kunne gi oss flere, nyanserte funn som kan gi oss bedre innsikt i politiets profesjonsforståelse, også i forhold til tjenestemenns forhold til kompetanse.

\section{Noter}

1. Cand.paed., arbeider som seniorrådgiver ved Politihøgskolen i Norge, Bacheloravdelingen i Oslo.

2. StudData er en database som skal gi grunnlag for panel- og forløpsstudier. Det er en større og langsiktig satsing som omfatter tyve profesjoner/profesjonsutdanninger. StudData er et samarbeidsprosjekt der elleve høgskoler og universitet deltar.

Senter for profesjonsstudier (SPS), Høgskolen i Oslo, leder og koordinerer oppbyggingen av databasen, som er finansiert av Norges forskningsråd og Høgskolen i Oslo (http://www.hio.no/content/view/full/9162).

3. Bred, generell kompetanse, Yrkesspesifikk kompetanse, Kunnskap om planlegging og organisering, Innsikt i regler og bestemmelser, Evne til kritisk refleksjon og vurdering av eget arbeid, Kreativitet, Evne til å arbeide under press, Praktiske ferdigheter, Evne til å jobbe selvstendig, samarbeidsevner, Evne til å ta initiativ, Muntlig kommunikasjonsevner, Skriftlig kommunikasjonsevne, Toleranse, evne til å verdsette ulike synspunkter, Lederevne, Evne til å ta ansvar og fatte beslutninger, Etisk vurderingsevne, Evne til innlevelse i andre menneskers situasjon.

\section{Litteratur}

Aamodt, Per Olav (2004): Studiestrategier og studieutbytte i Abrahamsen, Berit og Smeby, Jens-Christian (red), 2004: Sykepleiestudenten - Rekruttering, studietilfredshet og studieutbytte. HiO rapport $2004 \mathrm{nr}$ 7. Hogskolen i Oslo. Senter for profesjonsstudier.

Braten, Ole Andre (2010): Kvalitetsundersokelsen, 2010. Intern rapport, PHS.

Danielsson, Anders (2010): Framtidens polis och framtidens polisutbildning. I Nordisk tidsskrift for Kriminalvidenskab, 97(3), s. 295

Ellström, Per-Erik (1992): Kompetens, utbildning och laerande i arbetslivet. Stockholm: Fritzes.

Fekjær, Silje (2011): Police Students' Social Background, Attitudes and Career Plans. Upublisert artikkel.

Goodlad, J I and Associates (1979): Curriculum Inquiry: The study of curriculum Practice. New York: McGraw-Hill Book Company.

Graner, Rolf (2004): Patrullerande policers yrkeskultur. Lund, Socialhôgskolan, Lunds Universitet. 
Grimen, H. (2008). Profesjon og kunnskap. I: Molander, A. \& Terum, L.I. (Red), Profesjonsstudier. Oslo: Universitetsforlaget.

Gundhus, Helene (2009): For sikkerhets skyld: IKT, yrkeskulturer og kunnskapsarbeid i politiet. Oslo: Unipub.

Gundhus, Helene (red.), Hellesø-Knutsen, Kirsten (red, Wathne, Christin Thea (red.), (2010): Politivitenskap på egne ben: en essaysamling. Oslo: Politihøgskolen.

Handal, Gunnar \& Lauvås, Per (1983): På egne vilkår. Oslo: Cappelen.

Hansen, Hugo (2006): Utdrag fra kvalitetsundersøkelen. PHS-rapport 2006.

Heggen, Kåre og Damsgaard, Hilde Larsen (2010): Kva har utdanninga å seie for kompetansen? I Heggen, Kåre (2010): Kvalifisering for profesjonsutoving. Oslo: Abstrakt forlag AS.

Hove, 2010: Avsluttende studentevaluering $i$ bachelorutdanningen. Avgangsstudenters vurdering av undervisning og utdanning ved Politihøgskolen, kull 05-08. Intern rapport. Politihøgskolen.

Lagestad, Pål (2010): Fysisk styrke eller bare prat. Betydningen kjønn har i fysisk aktivitet og politiets ordenstjeneste. Doktorgradsavhandling Norges idrettshøgskole.

Lahn, Leif Christian og Jensen, Karen (2008): Profesjon og lcering. I Molander og Terum (Red)). Profesjonsstudier. Universitetsforlaget, Oslo.

Larsson, Paul (2010). Fra armesterke bondesønner til akademikerbarn: om rekrutteringen til politiyrket. Nordisk Tidsskrift for Kriminalvidenskab. 97(2), 150-159.

Leonardsen, Dag (1972): Politiet og utdannelsessporsmålet. Mellomfagsoppgave i kriminologi. Institutt for Kriminologi og Strafferett, UiO.

Lindholm, M (2006): Pedagogisk Grunder. Försvarsmakten, Stockholm.

Mastekaasa, A. (2003). Tilfredshet med profesjonsutdanningene. I: P.O. Aamodt \& L.I: Terum (Red.), Hvordan, hvor mye og hvorfor studerer studentene?: Om loringsmiljø, jobbpreferanser og forstålse av kompetanse i profesjonsutdanningene. Oslo: Hogskolen i Oslo, Senter for profesjonsstudier. (HiO-rapport; 8)

Molander, A. \& Terum, L.I. (2008). Profesjonsstudier - en introduksjon. I: Molander, A. \& Terum, L.I. (Red), Profesjonsstudier. Oslo: Universitetsforlaget.

NOU 1979:11, Politiutdanning

NTB - redaksjonen (2010, 28.januar). Frp vil hurtigutdanne politifolk. Hentet fra http://www.abcnyheter.no/nyheter/100128/frp-vil-hurtigutdanne-politifolk

Pedersen, Torun Dilland (2010): Teori vs praksis. I Magasinet Norsk Politi, 2010:1).

Politidirektoratet (2008): Politiet mot 2020: bemannings- og kompetansebehov i politiet. Oslo, Politidirektoratet.

Politihøgskolen (2006): Utkast til ny rammeplan for Bachelor-politiutdanning. Intern rapport, Politihøgskolen.

Schön, Donald (1991): The Reflective Practitioner. How professionals think in action. London: Ashgate.

Slagstad, R. (2008). Profesjoner og kunnskapsregimer. I: Molander, A. \& Terum, L.I. (Red) Profesjonsstudier. Oslo: Universitetsforlaget.

Smeby, J-C. (2008): Profesjon og utdanning. I: Molander, A. \& Terum, L.I. (Red), Profesjonsstudier. Oslo: Universitetsforlaget.

Sørensen, Anne-Stina (2010); Akademikerne og Politiet - kampen mellom teori og praksis. I Nordisk tidsskrift for Kriminalvidenskab. 97 (3), s. 298 